\title{
AUSTRALIA: COUNTRY REPORT ON HUMAN RIGHTS
}

\section{Jennifer Corrin *}

\section{INTRODUCTION}

The Commonwealth of Australia is relatively young in constitutional terms. Aboriginal and Torres Strait island peoples inhabited the continent for some 60,000 years prior to the arrival of British settlers in $1788 .{ }^{1}$ This settlement resulted in the widespread dispossession of Australia's indigenous people. The British established six colonies: New South Wales, South Australia, Victoria, Tasmania, Victoria and Queensland, each with sovereign status and legislative independence. In 1901 the colonies federated to become the Commonwealth of Australia. In 1943, Australia became independent from Britain ${ }^{2}$ and the last remaining ties to the British Parliament were cut in $1986 .^{3}$

Australia is the only country comprised of an entire continental land mass and is the sixth largest nation after Brazil, Canada, China, Russia and the United States of America. Its territory also includes the major island of Tasmania and a number of other islands in the Indian and Pacific Oceans. In spite of its large landmass, Australia has a relatively low population, estimated at 21.2 million people. ${ }^{4}$ Australians enjoy a high standard of living with a prosperous mixed economy. ${ }^{5}$

* Dr Jennifer Corrin is Executive Director, Asia Pacific Law, of the Centre for Public, International and Comparative Law and Associate Professor in the TC Beirne School of Law, University of Queensland, Australia. The author wishes to thank Robert Mullins for his valuable research assistance and her colleague Dr Anthony Cassimatis who kindly read through and commented on a draft of this document. Any errors are her own.

1 The first group of settlers numbered 1,035, of whom 850 were convicts: Australian Bureau of Statistics Special Article The State of New South Wales - Timeline of History (1998, ABS Catalogue No 1301.1) www.abs.gov.au (accessed 25 February 2008).

2 Statute of Westminster 1931 (United Kingdom) adopted with retrospective effect by the Australian Parliament in 1942.

3 Australia Act 1986 (Cth).

4 Australian Bureau of Statistics Population Clock www.abs.gov.au (accessed 25 February 2008).

5 Australia was ranked third in the United Nations' 2007 Human Development Index. United Nations Development Program Human Development Report 2007/2008: Fighting Climate Change: Human 
Human rights law in Australia is embodied in constitutional provisions; federal, state and territorial legislation; and the common law. Australia has not embraced the 'rights revolution' ${ }^{6}$ and only one state and one territory have legislative bills of rights.

\section{CONSTITUTIONAL STRUCTURE AND PROTECTION OF RIGHTS}

Australia is a constitutional monarchy. Its Constitution establishes a federal system of government and defines the law-making powers of the Commonwealth. Residual power vests in the states, with the Commonwealth Government having power to legislate only on matters falling within certain heads of power. ${ }^{7}$ States also have their own constitutions, as well as a structure of legislature, executive and judiciary. Australia's territories have legislative independence by virtue of federal legislation, ${ }^{8}$ but they do not have the same constitutional independence as the Australian states.

Australia does not have a constitutionally enshrined charter of human rights. The Constitution does protect some basic rights, but these protections are limited in scope and in the circumstances in which they operate. Some have been read down so far that they are almost totally ineffective. ${ }^{9}$ The High Court's approach to guarantees of human rights and individual liberties in the Constitution has been described as "replete with contradictions and uncertainty". ${ }^{10}$ The rights and freedoms dealt with in the Constitution are described below.

\section{A Right to Vote}

There is no longer any constitutional protection of the right to vote in Australian law. ${ }^{11}$ Although section 41 of the Constitution provides that all adults entitled to vote in a state election are entitled to vote in a Commonwealth election, the High Court has held that this only applies to adults who acquired the right to vote prior to universal franchise being granted in $1902 .{ }^{12}$

Solidarity in a Divided World (2007) hdr.undp.org/en/reports/global/hdr2007-2008 (accessed 18 February 2008).

6 Charles R Epp The Rights Revolution: Lawyers, Activists and Supreme Courts in Comparative Perspective (University of Chicago Press, Chicago, 1998).

7 Australian Constitution, s 51.

8 Australian Capital Territory (Self-Government) Act 1988 (Cth); Northern Territory (Self-Government) Act 1978 (Cth); Norfolk Island Act 1979 (Cth).

9 George Williams A Charter of Rights for Australia (University of New South Wales Press, Sydney, 2007) 35.

10 George Williams Human Rights under the Australian Constitution (Oxford University Press, Melbourne, 1999) 1.

11 Williams, above n 9, 36.

$12 R v$ Pearson; ex parte Sipka (1983) 152 CLR 254. 


\section{B Right to Trial by Jury}

Section 80 of the Constitution provides that "trial on indictment of any offence against any law of the Commonwealth shall be by jury." However, in $R v$ Archdall $^{13}$ the High Court held that the right to a jury trial is only available where the Commonwealth proceeds on indictment, which it can elect not to do. This renders the protection practically worthless. ${ }^{14}$ Moreover, there is no obligation on states, which prosecute the overwhelming majority of criminal cases, to abide by this guarantee.

\section{Freedom of Religion}

Section 116 of the Constitution limits the Commonwealth's ability to "make any law for establishing any religion", impose "any religious observance", prohibit "the free exercise of any religion" or impose a religious test "as a qualification for any office or public trust under the Commonwealth". To date, the High Court has not upheld a claim based on this section. ${ }^{15}$ Again, state legislatures are not required to abide by the requirements of section 116 .

\section{Protection against State Discrimination}

Section 117 prevents states from discriminating against residents of other states. For example, in Street $v$ Queensland Bar Association the High Court ruled that a New South Wales barrister could not be made to give up his practice in his home state in order to gain admission in Queensland. ${ }^{16}$

\section{E Right to Judicial Review of Government Action}

Section 75(v) of the Constitution provides that the High Court has original jurisdiction to review government actions by means of a prerogative writ or an injunction. Attempts to oust this jurisdiction have been held to be unconstitutional. It is an important source of legal review of government decision-making. ${ }^{17}$

\section{F Freedom of Interstate Trade}

Section 92 provides that "trade, commerce, and intercourse among the States ... shall be absolutely free." This emphatic language has given rise to difficulties of interpretation and the High Court has been divided over whether the section was directed solely to the elimination of discriminatory policies protecting one state against competition from other states, or whether it

\footnotetext{
$13 R v$ Archdall and Roskruge; Ex parte Carrigan (1928) 41 CLR 128.

14 Williams, above n 9, 36.

15 Ibid.

16 Street v Queensland Bar Association (1989) 168 CLR 461.

17 See Plaintiff S157/2002 v Commonwealth (2003) 211 CLR 476.
} 
conferred an individual right to freedom of interstate trade. In Cole $v$ Whitfield ${ }^{18}$ the High Court unanimously endorsed the former view. ${ }^{19}$

\section{G Right to 'Just Terms' for Property}

Under s 51(xxxi), the Commonwealth is only empowered to acquire property "on just terms". This does not apply to protect welfare rights of any sort. ${ }^{20}$ Neither does it restrict the actions of State legislatures, who are still able to acquire property without offering just compensation.

\section{H Implied Rights and Freedoms}

This is a nebulous and controversial area of constitutional interpretation under Australian law. Some judges have read into the Constitution an implication that certain rights and freedoms must be protected because they are fundamental to representative government. In Australia Capital Television Pty Ltd v Commonwealth a majority of the High Court was willing to imply a freedom of political communication into the Constitution. ${ }^{21}$ However, some High Court judges have subsequently expressed disagreement with this decision. ${ }^{22}$ There has been a similar and equally controversial suggestion regarding freedom of association. ${ }^{23}$

\section{COURTS AND COMMON LAW RIGHTS}

\section{A Commonwealth Courts}

The judicial power of the Commonwealth of Australia is vested by the Constitution in the High Court of Australia, in other federal courts created by the Commonwealth Parliament and in the State and Territory courts invested by Parliament with federal jurisdiction.

The High Court is vested with original and appellate jurisdiction. Original jurisdiction is conferred by section 75 of the Constitution in respect of all matters arising under any treaty; affecting consuls or other representatives of other countries; in which the Commonwealth, or a person suing or being sued on behalf of the Commonwealth, is a party; between States, or between residents of different States, or between a State and a resident of another State; and in which a writ

18 Cole $v$ Whitfield (1988) 165 CLR 360.

19 See also Castlemaine Tooheys Ltd v South Australia (1990) 169 CLR 436. See further Damien Geradin and Raoul Stewardson "Trade and Environment: Some Lessons from Castlemaine Tooheys (Australia) and Danish Bottles (European Community)" (1995) 44 ICLQ 41.

20 Williams, above n 9, 39.

21 Australian Capital Television Pty Ltd v Commonwealth No 2 (1992) 177 CLR 106.

22 McGinty v State of Western Australia (1996) 186 CLR 140; Australian Broadcasting Corporation v Lenah Game Meats Pty Ltd (2001) 208 CLR 199.

23 Mullholland v Australian Electoral Commission (2004) 220 CLR 181, McHugh and Kirby JJ, obiter; Gummow, Hayne and Callinan JJ dissenting; Gleeson CJ and Heydon J did not decide the issue. 
of mandamus or prohibition or an injunction is sought against an officer of the Commonwealth Government or of a federal court.

Under section 76 of the Constitution, the federal Parliament may also make laws conferring original jurisdiction on the High Court in certain other matters, including matters arising under or involving the interpretation of the Constitution. The High Court shares some of its jurisdiction under this section with the Federal Court of Australia. The High Court is also the final court of appeal in Australia. Jurisdiction has been vested by federal Parliament in the Federal Court and Federal Magistrates' Court (both creatures of statute) ${ }^{24}$ and the Family Court, which hears matters under the Family Law Act 1975 (Cth).

\section{B State and Territory Courts}

Most States and Territories have a four-tier court structure. At the top of the hierarchy is the Court of Appeal exercising appellate jurisdiction from the lower courts. Next is the Supreme Court, which has unlimited civil and criminal jurisdiction in all matters brought under State or Territorial laws, and in matters arising under Commonwealth laws, where jurisdiction has been conferred on Territory courts by the Commonwealth Parliament. Most criminal matters, whether arising under Commonwealth, State or Territory law, are dealt with by State or Territory courts.

The next level consists of an intermediate court, usually known as the District Court. At the bottom of the hierarchy is the Magistrates' Court, or the County Court as it is known in some jurisdictions. The intermediate and lowest courts have limited jurisdiction, both in geographical and monetary terms. In Queensland, for example, the Magistrates' Court has jurisdiction to hear civil disputes where the subject-matter does not amount to more than $\$ 50,000 .{ }^{25}$ Actions must be commenced in the court district where the matter first arose. ${ }^{26}$

\section{Common Law Rights}

The common law in Australia protect rights indirectly through an approach to statutory interpretation to the effect that "unless the parliament makes unmistakably clear its intention to abrogate or suspend a fundamental freedom, the courts will not construe a statute as having that operation." 27 The courts in Australia have accepted that various common law rights qualify for protection as rights, freedoms or immunities. These include:

\footnotetext{
24 Federal Court of Australia Act 1976 (Cth); Federal Magistrates Act 1999 (Cth).

25 Magistrates Court Act 1921 (Qld), s 4.

26 Ibid.

27 Re Bolton; Ex Parte Douglas Beane (1987) 162 CLR 514, 523 Brennan J.
} 
- The right of access to the courts; ${ }^{28}$

- Immunity from deprivation of property without compensation; ${ }^{29}$

- Legal professional privilege; ${ }^{30}$

- $\quad$ Privilege against self-incrimination; ${ }^{31}$

- Immunity from the extension of the scope of a penal statute by a court; ${ }^{32}$

- The right to procedural fairness when affected by the exercise of public power; ${ }^{33}$

- Freedom from extension of governmental immunity by a court; ${ }^{34}$

- Immunity from interference with vested property rights; ${ }^{35}$

- Immunity from interference with equality of religion; 36 and

- The right to access legal counsel when accused of a serious crime. ${ }^{37}$

Habeas corpus is also of relevance as it provides protection from false imprisonment. However, the common law has its limitations. For example, it does not recognise the right to privacy. ${ }^{38}$ Moreover, it has been held that there are no common law rights which lie so deep that Parliament cannot alter them with express and unambiguous wording. ${ }^{39}$ Nonetheless, common law rights

28 Magrath v Goldsborough Mort and Co Ltd (1932) 47 CLR 121, 134; Plaintiff S157, above n 18, esp 492; Wade v NSW Rutile Mining Co Pty Ltd (1969) 121 CLR 177; American Dairy Queen (Qld) Pty Ltd v Blue Rio Pty Ltd (1981) 147 CLR 677, 683.

29 Commonwealth $v$ Haseldell Ltd (1918) 25 CLR 552, 563; Durham Holdings Pty Ltd v State of NSW (2001) 205 CLR 399, paras 28-31.

30 Daniels Corporation International Pty Ltd v Australian Competition and Consumer Commission (2002) 213 CLR 543, para 11. See also R (Morgan Grenfell and Co Ltd) v Special Commissioner of Income Tax [2003] 1 AC 563, 606-607.

31 Pyneboard Pty Ltd v Trade Practices Commission (1983) 152 CLR 328; Australian Securities Investment Commission v Rich [2003] NSWSC 328.

32 Ex parte Fitzgerald Re Gordon (1945) 45 SR (NSW) 182, 186; Krakouer v R (1998) 194 CLR 202, para 62.

33 Commissioner of Police $v$ Tanos (1958) 98 CLR 383, 395-396.

34 Board of Fire Commissioners v Ardouin (1961) 109 CLR 105, 116; Puntoriero v Water Administration Ministerial Corporation (1999) 199 CLR 575, paras 33-37, 59-68, and 113.

35 Clissold v Perry (Minister for Public Instruction) (1904) 1 CLR 363, 373; Clunies Ross $v$ The Commonwealth (1984) 155 CLR 193, 199-200.

36 Canterbury Municipal Council v Moslem Alawy Society Ltd (1985) 1 NSWLR 525, 544 McHugh JA (NSWCA).

37 Dietrich $v$ R (1992) 177 CLR 292.

38 Victoria Park Racing and Recreation Grounds Co Limited v Taylor (1937) 58 CLR 479.

39 Building and Construction Employees and Builders Labourers' Federation of New South Wales v Minister for Industrial Relations (1986) 7 NSWLR 372 (NSWCA). 
provide an important source of protection against ambiguous, ill-considered or unintended interference by state and federal legislatures.

\section{HUMAN RIGHTS TREATIES}

\section{A Ratification of International Human Rights Treaties}

The Australian Government has ratified the majority of human rights treaties under international law. Sections 51 and 61 of the Constitution have the effect of vesting executive power exclusively in the Commonwealth government. Consequently, states have no power to sign or enter international treaties. The International Covenant on Economic, Social and Cultural Rights (ICESCR), ${ }^{40}$ International Covenant on Civil and Political Rights (ICCPR), ${ }^{41}$ International Convention on the Elimination of All Forms of Racial Discrimination (CERD), ${ }^{42}$ Convention on the Elimination of All Forms of Discrimination Against Women (CEDAW), ${ }^{43}$ Convention Against Torture and Other Cruel, Inhuman or Degrading Treatment and Punishment (CAT), ${ }^{44}$ and the Convention on the Rights of the Child ${ }^{45}$ have all been ratified with reservations by the Australian Government.

The ratification process alone has no effect in domestic Australian law. The Australian Government considers that it is a prerogative of the legislature to change international law to reflect domestic obligations under international treaties. In 1996, the Government declared that ratification of an international treaty created no legitimate expectation under domestic administrative law. ${ }^{46}$ That statement was read down by the Federal Court ${ }^{47}$ but those judgments were criticised by the High Court in Minister for Immigration and Multicultural Affairs Ex parte Lam. ${ }^{48}$ Protection of

40 International Covenant on Economic, Social and Cultural Rights (16 December 1966) 999 UNTS 3.

41 International Covenant on Civil and Political Rights (16 December 1966) 999 UNTS 171.

42 International Convention on the Elimination of All Forms of Racial Discrimination (7 March 1966) 660 UNTS 195.

43 Convention on the Elimination of all Forms of Discrimination Against Women (18 December 1979) 1249 UNTS 13.

44 Convention Against Torture and Other Cruel, Inhuman or Degrading Treatment and Punishment (10 December 1984) 1465 UNTS 85

45 Convention on the Rights of the Child (20 November 1989) 1577 UNTS 3.

46 Joint Statement by the Minister for Foreign Affairs, Alexander Downer, and the Attorney-General and Minister of Justice, Daryl Williams "The Effect of Treaties in Administrative Decision Making" (25 February 1997) Press Release.

47 See for example Tien v Minister for Immigration and Multicultural Affairs (1998) 89 FCR 80, 105; Luu v Minister for Immigration and Multicultural Affairs [2001] FCA 1136, para 61.

48 Re Minister for Immigration and Multicultural Affairs; Ex parte Lam (2003) 214 CLR 1. See further Wendy Lacey "A Prelude to the Demise of Teoh: The High Court Decision in Re Minister for Immigration and Multicultural Affairs; Ex parte Lam" (2004) 26 Sydney LR 131. 
human rights in Australian law must be afforded by an act of state or federal Parliament, under the common law, or in the Constitution itself.

\section{B Legal Response to International Human Rights Treaties}

\section{Commonwealth law}

There is no Commonwealth charter of human rights. Australia does have a national human rights protection body, the Human Rights and Equal Opportunity Commission (HREOC), ${ }^{49}$ which is guided by the principles of the ICCPR. The ICCPR is annexed to the Human Rights and Equal Opportunity Commission Act 1986 (Cth), which established HREOC, but takes no legal effect from the legislation. HREOC is comprised of a President and several specialist Commissioners. While the Commission can conciliate disputes, intervene in court proceedings, and hold inquiries into important human rights issues in the Australian community, it has extremely limited coercive powers.

\section{State legislation}

Two of Australia's states and territories now have statutory charters of human rights: the Human Rights Act 2004 (ACT) and the Charter of Human Rights and Responsibilities Act 2006 (Vict). The Human Rights Act (ACT) was Australia's first charter of rights and is largely modelled on the Human Rights Act 1998 (UK). It is an ordinary Act of Parliament, which may be amended or repealed by subsequent legislation. ${ }^{50}$ The Human Rights and Responsibilities Act was passed following a period of extensive consultation. ${ }^{51}$ It broadly reflects the content of the ICCPR, although several alterations have been made in order to more accurately reflect the values of the Victorian community. ${ }^{52}$ Two significant omissions are the right to life and the right to selfdetermination.

\section{Anti-discrimination law}

The Commonwealth and state legislatures have all passed legislation prohibiting racial and sexual discrimination. The key federal statutes are the Racial Discrimination Act 1975, Sex Discrimination Act 1984, Disability Discrimination Act 1992, and the Age Discrimination Act 2004. There are also several State Acts.

49 Human Rights and Equal Opportunity Commission www.hreoc.gov.au (accessed 7 February 2007) [hereafter HREOC].

50 Nationwide News Pty Ltd $v$ Willis (1992) 177 CLR 1, 43 and 48 Brennan J. See also G Brennan "Courts Democracy and the Law" (1991) 65 ALJ 32, 38. However, George Williams has observed that although repeal is possible in theory, it would be very difficult in practice. See Williams, above n 9, 73.

51 Williams, above n 9, 75-77.

52 Ibid, 78. 


\section{Criminal and other laws}

State criminal codes also protect certain rights, such as freedom from torture. ${ }^{53}$ Defamation laws are also in force to protect reputation rights. ${ }^{54}$

\section{Judicial Response to International Human Rights Treaties}

There is very limited discussion of human rights in the jurisprudence of Australia's highest courts. As mentioned above, international treaty obligations do not form part of domestic law until adopted by state or federal parliament. ${ }^{55}$ In Minister for Immigration and Ethnic Affairs $v$ Teoh, ${ }^{56}$ some steps were taken by the High Court towards permitting recognition of international treaty obligations in domestic law. In that case a majority of the High Court held that while the ratification of a treaty does not create substantive legal obligations, it does act as a statement by the executive that it would act in accordance with the treaty obligations. In making administrative decisions, the Government had to disclose its intention to depart from those expectations in order to afford procedural fairness to the parties involved. The Government has subsequently issued statements purporting to quash any expectation that such standards would be adhered to. ${ }^{57}$ Were these statements to be inapplicable, however, then the administrative actions of the Government may now be subject to the expectations created by international human rights obligations. ${ }^{58}$

International treaty obligations have also been applied to the interpretation of statutes in recent Australian case law. In Project Blue Sky v Australian Broadcasting Authority, ${ }^{59}$ for example, the High Court held that section 160(d) of the Broadcasting Services Act 1992 (Cth) obliged the Broadcasting Authority to act in a manner consistent with the Closer Economic Relations Agreement between Australia and New Zealand. However, the High Court held in Al-Kateb v Godwin $^{60}$ that there is no place for consideration of international law or the jurisprudence of other domestic jurisdictions if there is no ambiguity in the legislation to be applied, in that case the Migration Act 1958 (Cth). ${ }^{61}$

53 See for example Criminal Code Act 1899 (Qld), s 320A.

54 Ibid, s 365.

55 Simsek v Macphee (1982) 148 CLR 636; Dietrich v R, above n 38.

56 Minister for Immigration and Ethnic Affairs v Teoh (1995) 183 CLR 273.

57 Ryszard Piotrowicz and Stuart Kaye Human Rights in International and Australian Law (Butterworths, Chatswood, 2000) 202.

58 Ibid.

59 Project Blue Sky Inc v Australia Broadcasting Authority (1998) 194 CLR 355.

60 Al-Kateb v Godwin (2004) 219 CLR 562.

61 See Chu Kheng Lim v Minister for Immigration, Local Government and Ethnic Affairs (1992) 176 CLR 1. 


\section{A Separation of Powers and Judicial Independence}

Article 14(1) of the ICCPR guarantees that "everyone shall be entitled to a fair and public hearing by a competent, independent and impartial tribunal established by law". 62 Judicial independence forms the most basic element of this guarantee. The traditional separation of powers between the executive, legislature and judiciary is enshrined in the Constitution, ${ }^{63}$ although in practice the divide between executive and legislative powers has not been strictly observed. In 1991, the Australian Bar Association commented that: ${ }^{64}$

Power in contemporary Australian society resides increasingly with the executive arm of government.

Parliament, for all its strengths in other areas, does not consistently control, but rather is often controlled

by, the executive.

This fusion of executive and legislative functions is potentially damaging to procedural fairness and transparency in the law making process. However, the Australian system of government is centred on the notion of representative authority. As members of the Legislature, the Executive is deemed to be ultimately accountable to Parliament. Access to judicial review, as well as freedom of information legislation, are intended to act as obstacles against arbitrary executive decision-making.

Judges and commentators occasionally express their desire that the Executive and the Legislature increase their efforts to increase community confidence in the judiciary and its independence. ${ }^{65}$ In large part, however, Australia's constitutional and political institutions work to preserve the independence of the judiciary.

\section{B Access to Justice}

In Dietrich $v$ The Queen ${ }^{66}$ the High Court recognised that, under common law, a person has a right to access legal counsel when they are accused of a serious crime. There is no such protection in the case of less serious crimes. Australian Governments generally fund the running of legal aid programmes. ${ }^{67}$ However, these programmes are often severely limited in resources and in the

62 International Covenant on Civil and Political Rights, above n 42, art 14(1).

63 The separation of powers is not so enshrined in the States.

64 Australian Bar Association The Independence of the Judiciary (1991) www.austbar.asn.au/ (accessed 21 February 2008).

65 T H Smith "Court Governance and the Executive Model" (Judicial Conference of Australia Colloquium, Canberra, 6-8 October 2006) 43.

66 Dietrich $v$ R, above n 38.

67 See "Legal Aid" Australian Government: Attorney-General's Department www.ag.gov.au (accessed 21 February 2008). 
support they are able to offer their clients. A 2006 submission by National Legal Aid described the current level of Government support as inadequate to meet demand. 68

\section{Open Justice}

Generally court hearings in Australia are open and transparent. Highly effective reporting schemes are in operation. There is an exception for cases affecting national security, or those relating to minors, sexual assault victims, or parties whose identity should be otherwise concealed. ${ }^{69}$ The secrecy around national security hearings recently came under question during the high profile detention and interrogation of terrorist suspect Mohammed Haneef, who was held in detention under what was later revealed to be flimsy evidence. ${ }^{70}$ This suggests that the openness and transparency of hearing and detaining national security suspects may arise as an issue again in the future. The Anti-Terrorism Act (No 2) 2005 (Cth) has been heavily criticised in some quarters of the Australian community for allowing arbitrary detention, detention without charge, and for violating common law rights of habeas corpus in disregard of articles 9 and 14 of the ICCPR. ${ }^{71}$

The Federal Government has also demonstrated a degree of recalcitrance on the issues surrounding the detention and deportation of recently arrived immigrants and refugee claimants. Despite amendments to legislation designed to prevent arbitrary detention of children, recent reports by HREOC indicate that there are still grave concerns about the human rights implications of the detention centres, which continue to place strains on the mental health of the detainees. ${ }^{72}$ The Federal Government has recently announced major reforms to the mandatory detention laws to introduce a more compassionate approach. ${ }^{73}$

68 National Legal Aid Litigation Funding in Australia Discussion Paper (submission to Standing Commission of Attorneys-General, September, 2006) 3.

69 See for example Juvenile Justice Act 1992 (Qld), in part designed to protect the identity of young offenders and victims.

70 See Bar Association of Queensland Re Keim: Report to Legal Services Commissioner (17 December 2007) www.lsc.qld.gov.au/ (accessed 21 February 2008).

71 HREOC Submission to the Senate Legal and Constitutional Legislation Committee on the Provisions of the Anti-Terrorism Bill (No 2) 2004 (2004) www.hreoc.gov.au/ (accessed 21 February 2008).

72 HREOC Summary of Observations following the Inspection of Mainland Immigration Detention Facilities 2007 (2007) www.hreoc.gov.au/ (accessed 21 February 2008).

73 "Sweeping Changes to Mandatory Detention Announced" ABC News (29 July 2008) www.abc.net.au/ (accessed 22 September 2008). 


\section{A Language}

There is no constitutional or statutory right to language embedded in Australian law. English is Australia's de facto official language and some 84 per cent of all Australians speak it as their first language. ${ }^{74}$ Over 12 per cent of indigenous people (some 50,000 Australians) speak an indigenous language. There are more than 60 different languages spoken by Aboriginal and Torres Strait Islander Australians, including Kriol (an Australian creole), and two central Australian languages Pitjantjatjara and Warlpiri. ${ }^{75}$ Aside from English, the five most commonly spoken Australian languages in 2007 were Italian, Greek, Cantonese, Arabic, and Vietnamese. ${ }^{76}$ The Adult Migrant English Programme is run by the Australian Government as an initiative designed to improve the English proficiency of newly arrived migrants.

Many indigenous languages are lost or endangered. The government has launched its Maintenance of Indigenous Languages and Records Programme in order to help maintain and revive endangered Australian languages, as well as assist in the recording of linguistic data. ${ }^{77}$

\section{B Tensions between Culture and Other Rights}

In the past several decades, the legal issue that has become the most symbolic of Australian cultural division is the question of indigenous land rights. Following the High Court's decision in Mabo $v$ Queensland (No 2) ${ }^{78}$ the courts and legislatures have recognised indigenous title in a limited form. The decision in Mabo rejected the legal doctrine of terra nullius, which had held that Australia was an uninhabited continent that had been 'settled' by imperial forces. ${ }^{79}$

The Native Title Act 1993 (Cth) was subsequently passed by the Australian Government, which created a statutory framework for the recognition and protection of indigenous title. The High Court's Wik peoples $v$ Queensland decision in 1996 held that native title could exist concurrently with pastoral leases. ${ }^{80}$ In response, the Federal Government passed the Native Title Amendment Act 1998 (Cth) which many have criticised for imposing strenuous burdens on indigenous claimants

74 Australian Bureau of Statistics "Year Book Australia" (2007) ABS Catalogue No 1301.0.

75 Ibid.

76 Ibid.

77 Commonwealth of Australia "Incorporating the Fifth Report under the International Covenant on Civil and Political Rights and the Fourth Report under the International Covenant of Economic and Social Rights" (June 2006) 165 Common Core Document.

78 Mabo v Queensland (No 2) (1992) 175 CLR 1.

79 See for example Cooper v Stuart (1889) 14 App Cas 286.

80 Wik Peoples v Queensland (1996) 187 CLR 1. 
of native title. ${ }^{81}$ Presently, international human rights norms do not prescribe positive land rights obligations for the Australian Government to adhere to. ${ }^{82}$ HREOC publishes an annual Native Title Report, which monitors the performance of the Australian Government with respect to its human rights commitments. ${ }^{83}$ As of February 2008, none of HREOC's recommendations from the 2006 Report had been adopted by the Government.

The Government has, however, taken steps towards facilitating greater legal control amongst indigenous people over their traditional lands. The Aboriginal Land Rights (Northern Territory) Act 1976 (Cth) was amended in 2006 to allow for increased home ownership and land development in indigenous communities. ${ }^{84}$ On 13 February 2008 the newly elected Parliament of Australia passed a motion of the Prime Minister, Kevin Rudd, which offered a formal apology to indigenous Australians. ${ }^{85}$ Many Australians hope that this will open a new chapter in indigenous relations, and pave the way for a more practical reconciliation.

\section{EDUCATION}

\section{A Background}

School attendance is compulsory in all Australian states and territories between the ages of 8 and $15 .{ }^{86}$ State and territory Governments bear the principal responsibility for funding and maintaining the school system. A systematic review of their performance is beyond the scope of this report. The Australian Government has estimated that it contributes about $10 \%$ of the costs of running state schools, while the regional Governments contribute the remaining $90 \% .{ }^{87}$ A system of private schooling exists in tandem to the state-run school system.

\section{B Entitlements}

Secondary education is available without charge, although parents are required to pay for stationary and contribute towards other resources. Tertiary education students are required to

81 Richard Bartlett "A Return to Dispossession and Discrimination: The Ten Point Plan" (1997) 27 UWAL Rev 44.

82 HREOC "Appendix 3" Native Title Report 2006 (Report No 2, 2007) 185-205 www.hreoc.gov.au/social_justice/nt_report (accessed 26 February 2008). However, other international human rights obligations, such as the prohibition of racial discrimination, do have relevance to the post Wik legislation.

83 HREOC Native Title Reports www.hreoc.gov.au/social_justice/nt report/index.html\#2006 (accessed 26 February 2008).

84 Aboriginal Land Rights (Northern Territory) Amendment Act 2006 (Cth).

85 Kevin Rudd, Australian Prime Minister (Speech to House of Representatives, Canberra, 13 February 2008).

86 Commonwealth of Australia, above n 77.

87 Ibid, 155. 
contribute towards their higher education costs, which they may defer by obtaining a government loan through the HELP scheme.

\section{Discrimination}

In 2000, the United Nations Committee on Economic, Social and Cultural Rights expressed concern at the disparities in quality between the education available at state and private schools. ${ }^{88}$ The Australian Government has responded by stating that it acknowledges the freedom of most parents to choose the manner and method in which they wish to educate their children.

The English as a Second Language programme, run by the Government, offers a per capita payment to schools to provide for the training of newly arrived immigrants in the English language. ${ }^{89}$ A number of strategies have been devised to try to alleviate the significant disadvantages faced by indigenous students in the education system. ${ }^{90}$ Nonetheless, statistics show a decline in the number of indigenous students attending, and completing, secondary school. ${ }^{91}$ Indigenous students suffered a retention rate far below that of non-indigenous Australian students. ${ }^{92}$ 38 per cent of indigenous students are estimated to obtain only basic, or less than basic levels of literacy..$^{93}$

\section{RIGHT TO HEALTH}

\section{A Background}

Article 12 of the ICESCR recognises the right of everyone "to the enjoyment of the highest attainable standard of physical and mental health." ${ }^{94}$ It further commits state parties to the "creation of conditions which would assure to all medical service and medical attention in the event of sickness." 95 While the Australian Government plays a leadership role in policy creation and development, the states and territories are ultimately responsible for the provision of health services. ${ }^{96}$

88 Committee on Economic, Social and Cultural Rights Concluding Observations Australia (11 September 2000) E/C.12/1/Add 50, para 23.

89 Commonwealth of Australia, above n 77, 157.

90 Ibid, 160.

91 Ibid, 39.

92 Ibid, 41.

93 Ibid, 44.

94 International Covenant on Economic, Social and Cultural Rights, above n 41, art 12.

95 Ibid.

96 Commonwealth of Australia, above n 77, 142. 


\section{B Right to Healthcare Services}

The Medicare system is designed to provide "underlying universal access to the public health system." 97 It offers an 85 per cent rebate on the 'schedule' or standardised fee which is charged by medical practitioners. There is no obligation on medical practitioners to charge the schedule fee. Many choose to charge a higher fee. The 'Pharmaceutical Benefits Scheme' is also designed to subsidise the cost of purchasing pharmaceuticals on the Australian market. Eligible concession cardholders receive a substantial subsidy on their pharmaceutical purchases. In practice, Australia has essentially adopted an approach to medical services which is divided between Medicare cover and private health insurance. A subsidy is offered by the federal government to encourage Australians to take out private health insurance. As at June 2007, over nine million people had private health insurance cover, an estimated 44 per cent of the population. ${ }^{98}$

\section{Discrimination on the Basis of Health Status}

The Disability Discrimination Act 1992 (Cth) provides protection from discrimination or unequal treatment on the basis of disability. Disability is defined to include mental or physical illness. ${ }^{99}$ This protection is mirrored in state legislation. ${ }^{100}$ Federally, HREOC has jurisdiction to hear and conciliate discrimination complaints. In its 2005 Report, Not for Service: Experiences of Injustice and Despair in Mental Health Care in Australia, HREOC catalogued a number of disturbing experiences shared by mental health patients in the Australian system. Central findings of the Report were that mentally ill Australians experience great difficulty in accessing public and private care, struggle to access private health insurance coverage, and experience difficulties in dealing with social security authorities. ${ }^{101}$ This Report was followed by the Report of the Senate Committee on Mental Health in 2006, which again identified the issue of mental health as an area of strategic focus for the Australian Government. ${ }^{102}$

97 Ibid.

98 Australian Bureau of Statistics Year Book Australia 2008 (ABS Catalogue No 1301.0) www.abs.gov.au/ (accessed 4 March 2008).

99 Disability Discrimination Act 1992 (Cth), s 4.

100 Anti-Discrimination Act 1977 (NSW), Anti-Discrimination Act 1996 (NT), Anti-Discrimination Act 1991 (Qld), Equal Opportunity Act 1984 (SA), Anti-Discrimination Act 1998 (Tas), Equal Opportunity Act 1995 (Vic), Equal Opportunity Act 1984 (WA), Discrimination Act 1991 (ACT).

101 HREOC "Executive Summary" in Not for Service: Experiences of Injustice and Despair in Mental Health Care in Australia (2005) www.humanrights.gov.au/disability_rights/notforservice/report/ exec.html (accessed 2 March 2008).

102 Senate Select Committee on Mental Health A National Approach to Mental Health - From Crisis to Community Final Report (28 April 2006) www.aph.gov.au/ (accessed 2 March 2008). 


\section{Indigenous Health}

Indigenous health remains an area of great concern for all levels of Australian Government. The Government has documented a number of national reforms initiated with a view to improving the physical and mental health of indigenous Australians. ${ }^{103}$ In 2006, the Aboriginal and Torres Strait Islander Health Performance Framework Report concluded that there had been a 16 per cent reduction in death rates, and a 44 per cent reduction of infant mortality rates in Aboriginal communities since 1993. ${ }^{104}$ However, the health expectations of indigenous Australians, when compared with those of the general Australian community, are still appalling. In the years 19962001, there was an average difference of 17 years between the life expectancy of indigenous and non-indigenous Australians. ${ }^{105}$ Between 1999 and 2003, indigenous infants suffered from infant mortality rates three times that of non-indigenous infants. ${ }^{106}$ The statistics demonstrate a greater prevalence of chronic disease, communicable diseases, and severe mental health problems in Aboriginal communities. ${ }^{107}$

Significant measures have been taken to address these concerns, but the need for drastic and continued action remains. In December 2006, a group comprised of over 40 indigenous and nonindigenous health organisations published an open letter calling for urgent action to ensure aboriginal health equality in Australia. The letter stated that it is "inconceivable that a country as wealthy as Australia cannot solve a health crisis affecting less than 3 per cent of its population". ${ }^{108}$

\section{ENVIRONMENT}

The legislative protection of the environment is an important human rights concern in Australia, to ensure cultural and biological legacy in the years to come. In the Nuclear Weapons Case, ${ }^{109}$ the International Court of Justice confirmed that "the environment is not an abstraction, but represents

103 Commonwealth of Australia, above n 77, 148-149.

104 Ibid.

105 HREOC "Chapter 2: Achieving Aboriginal and Torres Straight Islander within a Generation - A Human Rights Based Approach" in Social Justice Report (2005) www.hreoc.gov.au/social_justice/sj_report/ (accessed 2 March 2008).

106 Ibid.

107 Ibid.

108 Coalition for Indigenous Health Equality "A Call for Health Equality for Aboriginal and Torres Strait Islander Peoples" (December 2006 Open letter www.hreoc.gov.au/social_justice/health/ (accessed 2 March 2008).

109 Legality of the Threat or use of Nuclear Weapons (Advisory Opinion) [1996] ICJ Rep 225. 
the living space, the quality of life, and the very health of human beings including generations unborn". 110

The Constitution has only one section protecting environmental rights. Section 100 protects the rights of states and their residents to use river waters for conservation or irrigation of land. This section has been interpreted as protecting both commercial and governmental interests, ${ }^{111}$ and is generally believed to restrict the ability of the Commonwealth Government to intervene in state governance of water management. ${ }^{112}$ In the celebrated Tasmanian Dam Case ${ }^{113}$ in 1983, the High Court established the right of the Government to interfere with the legislative powers of states in order to implement an international convention or treaty. ${ }^{114}$ The case validated the passing of the World Heritage Properties Conservation Act 1983 (Cth), which implemented the Convention Concerning the Protection of World Cultural and Natural Heritage. ${ }^{115}$

Legislation exists at both state and federal level that is designed to protect Australia's environmental security and cultural heritage. The Environmental Protection and Biodiversity Conservation Act 1999 (Cth) has a particular focus on matters of national environmental significance. It also provides for impact assessment and approvals processes where human development is likely to have an environmental impact. Parallel legislation exists in all Australian States and Territories. ${ }^{116}$

In December 2007 the Government announced its decision to ratify the Kyoto Protocol, marking its first real symbolic commitment to prevention of climate change. Australia will be a full member of the Kyoto Protocol by the end of March 2008. On 30 April 2007 Australia's State and Territory Governments commissioned an independent review of the effects of climate change on the Australian economy. The review was undertaken by Professor Ross Garnaut, an independent economist at the Australian National University. A draft report was released on 4 July 2008. This

110 Ibid.

111 Compare Australasian Temperance and General Mutual Life Assurance Society v Howe (1922) 31 CLR 290.

112 Morgan v Commonwealth (1947) 74 CLR 421; Commonwealth v Tasmania (Tasmanian Dam Case) (1983) 158 CLR 1 [Tasmanian Dam Case].

113 Tasmanian Dam's Case, above n 112.

114 Ibid.

115 World Heritage Convention Concerning the Protection of World Cultural and Natural Heritage (16 November 1972) 1037 UNTS 151.

116 Environmental Protection Act 1997 (ACT); Protection of the Environment Operations Act 1997 (NSW); Environmental Assessment Act 1994 (NT); Environmental Protection Act 1994 (Qld); Environmental Protection Act 1993 (SA); Environmental Management and Pollution Control Act 1994 (Tas); Environmental Protection Act 1970 (Vic); Environmental Protection Act 1986 (WA). 
report concluded that it was in Australia's best interests to react strongly to the threat of climate change, and to match the contributions of other developed nations. ${ }^{117}$ It is unclear which of the report's recommendations will be adopted by the Government as formal policy.

\section{CONCLUSION}

The status of human rights under Australian law reflects the nation's conservative approach to constitutional law reform. In general, human rights protection in Australia stems, to various degrees, from three discrete sources of Australian law: the Constitution; federal, state and territory legislation; and the common law. These sources do not provide a comprehensive regime for the protection of human rights in Australia. The rights protected by the Constitution could be described, at best, as modest. Furthermore, constitutional protections do not bind state legislatures, meaning that much legislative activity in the state system falls outside the ambit of their protection. While common law rights will affect the interpretation and application of ambiguous statutes, they do not provide a constitutional restraint on parliamentary action.

However, HREOC has had a positive influence on developing the human rights debate. Strong progress has been made in increasing statutory rights protections offered by Australian legislatures. Anti-discrimination legislation, which exists universally across federal, state and territory jurisdictions, has provided a vital form of statutory human rights protection and a guarantee of formal equality before the law. Further, statutory charters of rights have been passed by both the Victoria and Australian Capital Territory legislatures, showing the way forward for other Australian jurisdictions wishing to increase the human rights protections offered to Australian citizens.

There are also moves afoot to adopt a statutory charter of rights in two other Australian States. A report by the Tasmanian Law Reform Institute in October of 2007 recommended the adoption and implementation of a statutory charter of rights for the Tasmanian people. ${ }^{118}$ The institute expressed the view that "because the current protections of human rights in Tasmania are partial, disconnected and inaccessible, the enactment of a Charter of Human Rights would enhance human rights protection in Tasmania". ${ }^{119}$ In November 2007, a Consultation Committee established by the Western Australian Parliament also recommended the adoption of a statutory charter of rights. ${ }^{120}$ This report was met with caution by the Western Australian Attorney-General, who stated "human

117 Ross Garnaut Climate Change Review Draft Report (4 July 2008) www.garnautreview.org.au (accessed 22 September 2008).

118 Tasmanian Law Reform Institute A Charter of Rights for Tasmania (October 2007) Report No 10.

119 Ibid, para 4.1.49.

120 Consultation Committee for a Proposed Human Rights Act Final Report (November 2007) www.humanrights.wa.gov.au/documents/ (accessed 17 March 2008). 
rights protection was an objective best pursued at a national level". ${ }^{121}$ This was alluding to statements by the new Australian Attorney-General, Robert McClelland, that he would be investigating the viability of an Australian charter of rights. ${ }^{122}$

Any attempt to spread the legislative domain of human rights in Australia will be hotly contested. Conservative political forces remain resolutely opposed to the idea of a federal charter of rights. ${ }^{123}$ A parliamentary inquiry held by the Government of New South Wales in 2001 rejected a proposal for a Bill of Rights, finding that it ran counter to the doctrine of parliamentary supremacy, and was not in the best interests of the courts or the public to pass such legislation. ${ }^{124}$ This divide in Australian political debate shows that the progress of human rights protection under Australian law is likely to occur slowly, and in a piecemeal fashion. The examples set by the ACT and Victorian Parliaments, however, show that popular support for human rights protection is a political possibility.

121 Attorney-General of Western Australia "Human Rights Report Completed" (20 December 2007) www.acthra.anu.edu.au/articles/ (accessed 17 March 2008).

122 Jonathan Pearlman "Do-it-yourself charter to right future wrongs" (1 December 2007) Sydney Morning Herald Online www.smh.com.au/ (accessed 17 March 2008).

123 See Attorney-General of New South Wales "A Charter of Rights or A Charter of Wrongs?" (11 April 2008) The Australian Business www.theaustralian.news.com.au/ (accessed 22 September 2008). See also Williams, above n 9, 73.

124 Standing Committee on Law and Justice A New South Wales Bill of Rights (3 October 2001) www.parliament.nsw.gov.au/ (accessed 17 March 2008). 
(2009) 40 VUWLR 